\title{
Analisis Pemecahan Masalah Matematika Berdasarkan Pemanfaatan Teknologi Digital Siswa
}

\author{
Erika Nur Rosida $^{1 *}$, Lenny Kurniati², Ratih Kusumawati ${ }^{3}$. \\ $1,2,3$ Universitas Ivet \\ *erikarosida@gmail.com
}

\begin{abstract}
ABSTRAK
Perkembangan teknologi dewasa ini semakin berkembang pesat khususnya teknologi digital. Teknologi digital sudah memasuki berbagai aspek kehidupan khususnya bidang pendidikan. Hasil survei Global Digital Report tahun 2018 Indonesia menempati urutan keempat penggunaan internet tetapi pada hasil survei PISA tahun 2015 Indonesia justru menduduki peringkat 63 dari 70 negara. Tujuan penelitian ini (1) Mengetahui tingkat pemanfaatan teknologi digital siswa, (2) Mengetahui kemampuan pemecahan masalah siswa dan (3) Mengetahui pengaruh teknologi digital terhadap kinerja siswa dalam menyelesaikan permasalahan matematika. Metode yang digunakan dalam penelitian ini adalah metode kuantitatif deskriptif. Hasil penelitian munjukkan tidak ada siswa yang memanfaatkan teknologi digital dalam kategori rendah dan sebagian besar siswa mampu menyelesaikan permasalahan yang diberikan. Hasil output SPSS menunjukkan kedua variabel mempunyai hubungan yang positif dan variabel bebas berpengaruh terhadap variabel terikat. Berdasarkan hasil penelitian dapat disimpulkan bahwa (1) tidak ada siswa yang pemanfaatan teknologinya tergolong rendah, (2) kemampuan pemecahan masalah siswa sudah cukup baik, (3) pemanfaatan teknologi digital yang baik maka akan berpengaruh terhadap kemampuan pemecahan masalah menjadi baik pula.
\end{abstract}

Kata Kunci: pemanfaatan teknologi digital, kemampuan pemecahan masalah.

\section{ABSTRACT}

Technology development are growing rapidly especially digital technology. Digital technology has entered various aspect of life especially in the field of education. The result of the 2018 Global Digital Report Indonesia ranked fourth in internet usage,but based on the 2015 PISA survey Indonesia occupied 63 of 70 countries. The research purposes: (1) know the level of utilization of digital technology, (2) know students problem solving skills, (3) know the effect of digital technology on students performance in completing mathematical problem. The method in this research is descriptive quantitative method. The result showed there no students who utilized digital technology in the low category and moststudents are able to solve the given problem. The result of the SPSS output show that both variables have a positive relationship and the independent variabl influences the dependent variable. Based on the result of the research it can be concluded that (1) there is no students the utilization of technology is relatively low, (2) students problem solving skills are good enough, (3) good use of digital technology will affect the ability to solve problems as well.

Keywords: utilization of digital technology, problem solving skill. 


\section{PENDAHULUAN}

Indonesia menempati urutan keempat rata-rata penggunaan internet perhari, jumlah yang tercatat sudah mencapai 132 juta jiwa dengan 60\% dari jumlah tersebut mengakses internet menggunakan smartphone (Global Digital Report: 2018). Hal ini menunjukkan bahwa mayoritas penduduk indonesia sudah sangat lekat dengan teknologi digital dalam kesehariannya. "Teknologi digital yaitu teknologi yang dioperasikan dengan menggunakan sistem komputerisasi, sistem tersebut didasari dari bentuk informasi sebagai nilai numeris 0 dan 1 yang mengidentifikasikan tombol hidup dan mati.Teknologi digital juga dapat dikatakan teknologi nirkabel, maksudnya adalah teknologi ini memanfaatkan signal sebagai sarana penghubung kepada medianya sebagai penyampai pesan" (Muhasim: 2017).

Asosiasi Penyelenggara Jasa Internet Indonesia juga mensurvei penggunaan internet berdasarkan jenjang pendidikan, jenjang S3/S2 88,24\%, jenjang S1/Diploma 79,23\%, SMA 70,54\%, SMP 48,53\%, SD 25,1\% dan tidak sekolah 5,45\%. Berdasarkan kedua survei tersebut menunjukkan bahwa masyarakat Indonesia sudah termasuk pengguna internet yang cukup tinggi. Sejalan dengan Peraturan Menteri Pendidikan dan Kebudayaan No. 65 Tahun 2013 tentang pemanfaatan teknologi informasi untuk meningkatkan efisiensi dan efektivitas pembelajaran. Maka berdasarkan hasil survei diatas sangat berpotensi untuk memanfaatkan teknologi digital untuk meningkatkan efesiensi dan efektivitas pembelajaran yang dilakukan.

Hasil survei tersebut bertolak belakang dengan kemampuan matematika siswa yang memprihatinkan. Dilansir dari the Organisation for Economic Co-operation and Development (OECD) tahun 2015 yang menggagas Programe for Internasional Students Assessment (PISA) menunjukkan hasil bahwa kemampuan matematika siswa Indonesia menduduki peringkat 63 dari 70 negara yang disurvei. Kemampuan matematika diklasifikasikan menjadi lima yaitu, pemahaman matematis, pemecahan masalah, komunikasi matematis, koneksi matematis dan penalaran matematis (Latif: 2016). Kemampuan pemecahan masalah merupakan hal yang sangat penting sehingga hampir disetiap standar kompetensi dan kompetensi dasar ditegaskan perlunya pemecahan masalah (Akbar, dkk: 2018). Sejalan dengan Lailiyah (2011) yang menyatakan bahwa kemampuan pemecahan masalah sangat penting karena bermanfaat dalam kehidupan sehari-hari.

Wilson (1993:57) juga mengatakan "problem solving has special importance in the study of mathematics". Sedangkan menurut Ardiyani (2016) dalam penelitiannya pemecahan masalah adalah suatu upaya untuk merespon atau mengatasi halangan atau kendala ketika suatu jawaban atau metode jawaban dari suatu keadaan belum ditemukan. Penelitian ini menggunakan tahapan Polya sebagai acuan mengukur kemampuan pemecahan masalah siswa. Tahapan menurut Polya terdiri dari 4 langkah yaitu memahami masalah, merencanakan penyelesaian, melakukan rencana penyelesaian dan mengecek kembali hasil penyelesaian.

Berdasarkan uraian di atas terdapat beberapa rumusan masalah, yaitu: (1) Bagaimana tingkat pemanfataan teknologi digital siswa. (2) Bagaimana kemampuan pemecahan masalah siswa. (3) Apakah tingkat pemanfaatan teknologi digital berpengaruh terhadap kinerja siswa dalam menyelesaikan permasalahan matematika. Penelitian ini bertujuan: (1) Mengetahui tingkat pemanfaatan teknologi digital siswa. (2) Mengetahui kemampuan pemecahan masalah siswa. (3) Mengetahui pengaruh teknologi digital terhadap kinerja siswa dalam menyelesaikan permasalahan matematika. 


\section{METODE}

Jenis penelitian ini adalah kuantitatif deskriptif, dengan menggunakan tiga instrumen penelitian yaitu angket, soal tes dan pedoman wawancara. Penelitian dilakukan di SMK Negeri 3 Kendal. Populasi penelitian yaitu seluruh kelas Rekayasa Perangkat Lunak yang berjumlah 3 kelas dengan masing-masing kelas 36 siswa, karena XI RPL (dari sekian jurusan yang terdapat di SMK Negeri 3 Kendal hanya kelas RPL yang sudah memanfaatkan teknologi seperti pembelajaran menggunakan power point dan tugas-tugas diberikan melalui web.

\subsection{Prosedur Penelitian}

Pengambilan sampel penelitian dilakukan sesuai dengan pedoman Arikunto (2010) yang menyatakan bahwa jika populasi lebih dari 100 maka sampel dapat diambil 20\% dari jumlah populasi, Maka sampel diambil secara acak kelas XI RPL 1. Variabel pada penelitian ini ada dua yaitu pemanfaatan teknologi digital (X) dan kemampuan pemecahan masalah (Y).

Penelitian dilakukan pada tanggal 16-21 Juli 2019 dengan melalui tiga tahapan. Tahap pertama penyebaran angket, tahap kedua penyelesaian soal tes yang berbentuk pemecahan masalah dan tahap ketiga wawancara guna memperkuat data yang telah diperoleh.

\subsection{Desain Penelitian}

Pada penelitian ini menganalisis tingkat pemanfaatan teknologi digital, tingkat kemampuan pemecahan masalah siswa dan menganalisis pengaruh pemanfaatan teknologi digital terhadap kemampuan pemecahan masalah siswa.

Pemanfaatan teknologi digital diukur menggunakan skor angket tertutup dengan empat alternatif pilihan jawaban. Alternatif pilihan jawaban, menggunakan skala Likert dimana menurut Sugiyono (2010: 134-135) pernyataan positif dengan respon sangat sesuai diberikan skor 4, respon sesuai diberikan skor 3, respon tidak sesuai diberikan skor 2, dan respon sangat tidak sesuai diberikan skor 1. Sedangkan pernyataan negatif diberikan skor sebaliknya. Pemanfaatan teknologi digital siswa dibagi menjadi tiga kategori yaitu kategori tinggi, sedang, dan rendah. Kategori ditentukan berdasarkan penelitian Akbar (2018) yang telah dimodifikasi. Indikator pemanfaatan teknologi digital pada penelitian ini bersumber dari Penelitian Ayunthara (2016). Indikator yang digunakan yaitu, siswa mengetahui teknologi digital, memanfaatkan teknologi digital sebagai alat informasi dan komunikasi, dan memanfaatkan teknologi untuk pembelajaran matematika.

Kemampuan pemecahan masalah siswa diukur menggunakan soal tes. Soal tes yang diberikan berbentuk pemecahan masalah. Siswa dianggap mampu memecahkan masalah apabila dapat menyelesaikan permasalahan yang disajikan dengan benar sesuai dengan tahapan-tahapan Polya, dengan pedoman penskoran berdasarkan pada penelitian Akbar (2018) yang telah dimodifikasi. 
Tabel 1. Pedoman Penskoran

\begin{tabular}{llc}
\hline \multicolumn{1}{c}{ Tahapan } & \multicolumn{1}{c}{ Indikator } & Skor \\
\hline Memahami masalah & tidak mengidentifikasi unsur atau identifikasi unsur salah & 0 \\
& mngidentifikasi unsur dengan benar & 1 \\
Merencanakan Penyelesaian & strategi yang dibuat tidak mengarah pada jawaban & 0 \\
& strategi yang dibuat sudah tepat & 1 \\
Melakukan Rencana Penyelesaian & terdapat penyelesaian masalah tetapi tidak sesuai & 0 \\
& terdapat penyelesaian masalah tetapi salah dalam perhitungan & 1 \\
& penyelesaian masalah tepat dan benar & 2 \\
Mengecek Kembali & kesimpulan yang diberikan salah & 0 \\
& kesimpulan yang diberikan benar & 1 \\
\hline
\end{tabular}

Analisis pengaruh pemanfaatan teknologi digital terhadap kemampuan pemecahan masalah siswa dilakukan dengan cara analisis korelasi dan regresi menggunakan skor angket dan skor soal tes. Skor hasil angket dan soal tes diolah menggunakan software SPSS Teknik analisis korelasi yang digunakan adalah teknik analisis Korelasi Product Moment yang digunakan untuk mengetahui besar dan arah hubungan pemanfaatan teknologi digital dan kemampuan penyelesaian permasalahan matematika siswa kelas XI RPL 2 SMK N 3 Kendal. Analisis regresi merupakan analisis yang berusaha untuk meramalkan dan memperkirakan secara matematis apa yang akan terjadi pada masa depan berdasarkan data yang telah diperoleh dari hasil penelitian.

\section{HASIL DAN PEMBAHASAN}

Hasil pemanfaatan teknologi digital siswa yang diukur menggunakan angket penelitian dan telah dikategorikan menjadi tiga dapat dilihat pada tabel dibawah ini:

\begin{tabular}{ccc} 
Tabel 2. Kategori Pemanfaatan & Teknologi Digital \\
\hline Kriteria Skor & Kategori & Jumlah siswa \\
\hline $40 \leq$ skor $\leq 52$ & Tinggi & 15 siswa \\
$27 \leq$ skor $\leq 39$ & Sedang & 17 siswa \\
$13 \leq$ skor $\leq 26$ & Rendah & 0 siswa \\
\hline
\end{tabular}

Berdasarkan hasil penelitian tidak terdapat siswa yang termasuk dalam kategori rendah, hal ini sesuai dengan hasil survei Global Digital Report (2018) dan Asosiasi Penyelenggara Jasa Internet Indonesia yang menyatakan indonesia termasuk dalam negara yang cukup tinggi memanfaatan teknologi. Sejalan dengan penelitian yang dilakukan Abdullah (2018) yang menyatakan bahwa teknologi informasi mempunyai kontribusi yang besar. Sebagai contoh dalam pelaksanaan wawancara siswa lebih memilih wawancara melalui aplikasi whatsapp dibandingkan bertatap muka langsung dengan peneliti. Didukung dengan penelitian Putra, dkk (2017) yang menyatakan bahwa siswa lebih tertarik terhadap sarana yang bersifat kekinian dan terbiasa digunakan sehari-hari. Hal ini terbukti dengan rata-rata skor tertinggi angket adalah pada pernyataan bahwa siswa menggunakan smartphone untuk alat komunikasi antar teman, guru, atau orang lain.

Kemampuan pemecahan masalah siswa diukur mebggunakan sol tes. Siswa dikatakan mampu memecahkan permasalahan matematika apabila dapat menyelesaikan soal dengan 
benar dan tepat sesuai dengan tahapan Polya. Hasil kemampuan pemecahan masalah siswa dapat dilihat pada Tabel 3.

Tabel 3. Kategori Kemampuan Pemecahan Masalah

\begin{tabular}{ccc}
\hline Kriteria skor & Jumlah siswa & Kategori \\
\hline Nilai $<75$ & 11 siswa & Tidak mampu \\
Nilai $>75$ & 21 siswa & Cukup mampu \\
Nilai $=100$ & 0 siswa & Mampu \\
\hline
\end{tabular}

Hasil pengukuran kemampuan pemecahan masalah siswa terlihat 11 siswa yang termasuk dalam kategori tidak mampu adalah siswa yang pemanfaatan teknologi digitalnya sedang, sedangkan 21 siswa yang termasuk dalam kategori cukup mampu merupakan siswa yang pemanfaatan teknologi digitalnya tinggi dan sedang. Analisis skor siswa berdasarkan tahapan Polya sebagian besar siswa tidak mendapatkan skor pada Tahap ke 4. Sejalan dengan penelitian Utami \& Wutsqa (2017) yang menyatakan bahwa tahapan ke-4 Polya presentasenya lebih kecil daripada tahap lainnya. Setelah selesai menghitung siswa rata-rata tidak memberikan kesimpulan pada jawabannya padahal kesimpulan sangat penting untuk mengetahui pemahaman siswa terhadap soal yang diberikan. Selain itu siswa tidak mendapat skor yang maksimal pada tahap ke 3. Mereka rata-rata kurang teliti dalam melakukan perhitungan sehingga menghasilkan angka yang berdeda.

Berdasarkan hasil wawancara siswa, yang masuk dalam pemanfaatan teknologi sedang mengemukakan bahwa mereka belum sepenuhnya memahami soal yang diberikan dan mereka juga tidak yakin dengan konsep yang digunakan untuk meyelesaikan soal. Sedangan kelompok tinggi mereka lebih yakin dengan konsep yang digunakan karena pada saat akan mengerjakan mereka membaca buku dan mencari langkah penyelesaian melalui internet. Sehingga siswa kelompok tinggi lebih memahami soal yang diberikan dan yakin dengan konsep yang digunakan, namun terkadang mereka terburu-buru dan menyebabkan salah perhitungan.

Hasil penelitian kemampuan masalah matematika sudah cukup baik hal ini ditunjukkan mayoritas siswa sudah menyelesaikan masalah sesuai dengan tahapan Polya. Kesalahan yang sering siswa lakukan adalah tidak memberikan kesimpulan akhir pada jawaban penyelesaiannya. Selain itu, pada tahap ketiga siswa kurang teliti dalam melakukan perhitungan. Pada tahap pertama dan kedua rata-rata siswa sudah mampu dan tepat dalam menuliskan pada jawaban penyelesaian. Hal ini dikarenakan siswa hanya membuka situs brainly yang telah menyediakan cara lengkap untuk mengerjakan permasalahan yang diberikan, tetapi pada kenyataannya siswa masih banyak melakukan kesalahan hal ini disebabkan karena siswa hanya sekedar menjiplak dan menuliskan apa yang ada di brainly tanpa meneliti dan memahami cara menghitung. Dibuktikan dari rata-rata siswa menjawab tidak setuju pada pernyataan selalu mengakses buku elektronik sebagai bahan belajar.

Analisis pengaruh teknologi digital terhadap kemampuan pemecahan masalah matematika menunjukkan hasil bahwa pemanfatan teknologi digital mempunyai hubungan yang positif sebesar 0,468. Hasil analisis regresi juga menunjukkan bahwa pemanfaatan teknologi digital berpengaruh terhadap kemampuan pemecahan masalah siswa yang ditunjukkan dengan persamaan $Y=-146,680+5,447 X$. Berarti bahwa setiap penambahan $1 \%$ pemanfaatan teknologi dgital maka kemampuan pemecahan masalah akan meningkat 5,447. Besar presentase pengaruh pemanfaatan teknologi digital sesuai dengan koefisien 
determinasi $\left(R^{2}\right)$ yaitu $46,8 \%$ dan $53,2 \%$ dipengaruhi faktor lain. Sejalan dengan penelitian Yunianto dan Fitrihana (2016) yang menyatakan bahwa tingkat pemanfaatan smartphone atau dalam penelitian ini termasuk dalam teknologi digital dengan hasil belajar siswa mempunyai hubungan yang kuat. Hasil olah data analisis korelasi dan regresi dapat dilihat pada Tabel 5.

Tabel 5. Hasil Analisis Korelasi (Model Summaryb)

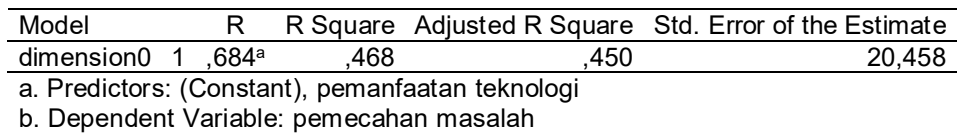

Tabel 6. Hasil Analisis Regresi (Coefficients ${ }^{\mathrm{a}}$ )

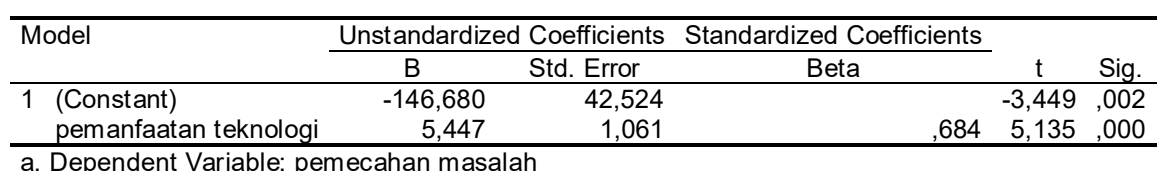

Hasil penelitian menunjukkan siswa yang pemanfaatan teknologi digitalnya tinggi mendapat nilai yang tinggi pula atau dalam kategori cukup mampu, Semakin tinggi intensitas penggunaan smartphone maka semakin tinggi pula prestasi belajar anak (Jauhar, dkk: 2015). sedangkan siswa yang pemanfaatan teknologinya sedang tidak semuanya mampu memecahkan permasalahan yang disajikan. Sejalan dengan penelitian yang dilakukan oleh Srinadi (2015) yang menyatakan bahwa semakin besar penggunaan internet sebagai media belajar maka semakin meningkat pula motivasi belajar siswa. Jika motivasi belajar siswa meningkat maka akan semakin baik juga kemampuan untuk menyelesaikan masalah matematika.

Berdasarkan hasil wawancara siswa yang termasuk kategori sedang dalam pemanfaatan teknologi digital mereka sering memanfaatkan teknologi digital untuk mencari materi, mencari cara penyelesaian soal ataupun hanya sekedar mencari informasi tentang materi-materi yang dijarkan, tetapi mereka juga mengimbangi dengan membaca buku pelajaran, jadi siswa yang termasuk dalam kategori tinggi menyelesaikan permasalahan matematika dengan cara yang seimbang yaitu membaca buku pelajaran dan memanfaatkan teknologi digital. Sedangkan siswa yang masuk kategori sedang dalam memanfaatkan teknologi digital mereka tidak terlalu sering memanfaatkan teknologi digital untuk membantu menyelesaikan permasalahan matematika. Siswa dalam kategori sedang mereka akan memanfaatkan teknologi digital ketika mereka merasa sangat kesulitan dan tidak paham dengan permasalahan yang disajikan.

\section{SIMPULAN}

Berdasarkan hasil penelitian terbukti bahwa pemanfaatan teknologi digital siswa tidak ada yang masuk dalam kategori rendah sesuai dengan survei yang dilakukan Asosiasi Penyelenggara Jasa Internet Indonesia dan Global Digital Report tahun 2018. Kemampuan pemecahan masalah matematika tidak terdapat siswa yang masuk dalam kategori mampu, namun semua siswa yang termasuk dalam kategori pemanfataan teknologi digital tinggi sudah cukup mampu memecahkan masalah matematika. 
Pemanfaatan teknologi digital berpengaruh terhadap kemampuan pemecahan masalah matematika siswa ditunjukkan dari hasil analisis korelasi sebesar 0,468 dan regresi yang menunjukkan terdapat pengaruh pemanfaatan teknologi digital terhadap pemecahan masalah matematika siswa. $46,8 \%$ pemecahan masalah matematika siswa dipengaruhi oleh teknologi digital dan 53,2\% dipengaruhi faktor lain.

\section{DAFTAR PUSTAKA}

Abdullah, H.A. 2018. Pengaruh Pemanfaatan Teknologi Informasi dan Motivasi Belajar Terhadap Perilaku Belajar Siswa. Jurnal Iqra' Vol.3. No.1.

Akbar, P, dkk. 2018. Analisis Kemampuan Pemecahan Masalah dan Disposisi Matematik Siswa Kelas XI SMA Putra Juang dalam Materi Peluang. Journal Cendekia: Jurnal Pendidikan Matematika. Volume 2, No. 1.

Ardiyani, S.A. 2016. Identifikasi Kemampuan Pemecahan Masalah dan Self Efficiacy Matematika Siswa Kelas VIII dalam Setting Pembelajaran Learning Cycle 7E. Skripsi. Semarang : Fakultas Matematika dan Ilmu Pengetahuan Alam Universitas Negeri Semarang.

Arikunto, S. 2010.Prosedur Penelitian Suatu Pendekatan Praktek. Jakarta : PT Rineka Cipta.

Ayunthara. A. 2016. Pengaruh Penggunaan Teknologi Informasi, Lingkungan Sekolah dan Manajemen Waktu Terhadap Prestasi Belajar Ekonomi Siswa Kelas X SMA NEGERI 10 Yogyakarta Tahun Ajaran 2015/2016. Skripsi. Yogyakarta : Fakultas Ekonomi Universitas Negeri Yogyakarta.

Jauhar, dkk. 2015. Pengaruh Intensitas Penggunaan Smartphone dan Komunikasi Orangtua Anak Terhadap Prestasi Belajar Anak. Ejournal Undip.

Lailiyah, S \& Hariyanti, A. 2017. Pengembangan Perangkat Pembelajaran Berbasis Masalah Matematika denan Strategi Draw A Picture. Prosiding Seminar Nasional Matematika dan Pendidikan Matematika STKIP Siliwangi. Volume 5, Tahun 2017.

Latif, S \& Akib, I. 2016. Mathematical Connection Ability In Solving Mathematics Problem Based On Initial Abilities Of Students At SMPN 10 Bulukumba. Jurnal Daya Matematis, Volume 4 No. 2.

Muhasim. 2017. Pengaruh Tehnologi Digital Terhadap Motivasi Belajar Peserta Didik. Jurnal Studi Keislaman dan Ilmu Pendidikan. Volume 5, Nomor 2.

Putra, dkk. 2017. Pengaruh Penggunaan Media Pembelajaran Berbasis Aplikasi Android Terhadap Hasil Belajar Siswa. Jurnal Inovasi Pendidikan Kimia, Vol. 11, No. 2.

Srinadi, P. N. 2015. Analisis Pengaruh Penggunaan Teknologi Informasi Sebagai Media Pembelajaran Terhadap Motivasi Belajar Siswa. Konferensi Nasional Sistem \& Informatika 2015. STMIK STIKOM Bali.

Utami, R.W \& Wutsqa, D.U. 2017. Analisis Kemampuan Pemecahan Masalah Matematika dan Self-Efficacy Siswa SMP Negeri di Kabupaten Ciamis. Jurnal Riset Pendidikan Matematika.

Yunianto, E \& Fitrihana, N. 2016. Hubungan Pemanfaatan Smartphone Dengan hasil Belajar Siswa Kelas X Program Keahlian Tata Busana Di SMK N 4 Yogyakarta. Jurnal Pendidikan Teknik Busana UNY. Edisi Juni 2016. 